\title{
Colorectal Cancer Genetics, Incidence and Risk Factors: In Search for Targeted Therapies
}

This article was published in the following Dove Press journal: Cancer Management and Research

\author{
Rodney Hull (D) \\ Flavia Zita Francies' \\ Meryl Oyomno (iD ${ }^{2}$ \\ Zodwa Dlamini (iD) 1,3 \\ ISAMRC/UP Precision Prevention \& \\ Novel Drug Targets for HIV-Associated \\ Cancers (PPNDTHAC) Extramural Unit, \\ Pan African Cancer Research Institute \\ (PACRI), University of Pretoria, Faculty of \\ Health Sciences, Hatfield 0028, South \\ Africa; ${ }^{2}$ Department of Surgery, Faculty \\ of Health Sciences, Steve Biko Academic \\ Hospital and the University of Pretoria, \\ Pretoria 0007, South Africa; ${ }^{3}$ Faculty of \\ Health Sciences, School of Clinical \\ Medicine, University of the \\ Witwatersrand, Parktown 2193, South \\ Africa
}

\begin{abstract}
Each year, colorectal cancers (CRCs) affect over a quarter of a million people. The risk of developing CRC in industrialized nations is approximately $5 \%$. When the disease is localised, treatment success rates range from $70-90 \%$; however, advanced CRC has a high mortality rate, consistently ranking in the top three causes of cancer-related deaths. There is a large geographic difference in global distribution, and CRC is predominantly associated with developed countries and a Western lifestyle and diet. As such, the developed world accounts for more than $63 \%$ of all cases of CRC. Geographic variations also predict cancer outcomes, which differ between racial and ethnic groups. This variation is due to inequalities in wealth, differences in the exposure to risk factors and barriers to high-quality cancer prevention, early detection and treatment. The aim of this paper was to review CRC in lowand middle-income countries such as South Africa, India, Brazil and China, and compare them with high-income countries such as the United States of America and the United Kingdom. It is important to note that these economically less developed countries, with historically low CRC rates, are experiencing an increased frequency of CRC. The review also discusses biological markers and genetic pathways involved in the development of colorectal cancer. Genes known to be responsible for the most common forms of inherited CRCs have also been identified but more remain to be identified. This would provide more candidate genes to be added to known biomarkers. CRC burden can be controlled through the widespread application of existing knowledge, such as reduced smoking habits, vaccination, early detection and promoting physical activity, accompanied by a healthy diet. An increased understanding of the molecular mechanisms and events underlying colorectal carcinogenesis will enable the development of new targets and therapeutic drugs.
\end{abstract}

Keywords: colorectal cancer, WNT signaling pathway, RAS pathway, alcohol consumption, physical activity

\section{Introduction}

Globally, colorectal cancers (CRCs) affect over a quarter of a million people each year. The risk of developing $\mathrm{CRC}$ in industrialized nations is approximately $5 \%$ while the risk of developing an adenoma, a noncancerous colon tumor is approximately $20 \%$. When the disease is localized or confined, effective treatment success rates range from 70-90\%; however, advanced CRC has a high mortality rate, consistently ranking in the top three causes of cancer-related death worldwide. ${ }^{1}$ The incidence of CRC has increased in developing countries; subsequently, there is an increase in mortality rates. In South America and Eastern Europe, lower amounts of resources than in wealthier countries means that a rapid rise in both $\mathrm{CRC}$ incidence and mortality rates has been observed in these
Correspondence: Zodwa Dlamini SA-MRC/UP Precision Prevention \& Novel Drug Targets for HIV-Associated Cancers (PPNDTHAC) Extramural Unit, Pan African Cancer Research Institute (PACRI), University of Pretoria, Faculty of Health Sciences, Room 4.35 Pathology Building, Hatfield 0028, South Africa Tel +27 76l474878

Email Zodwa.Dlamini@up.ac.za 
areas. ${ }^{1}$ The increase in CRC cases has not been accompanied by an increase in screening or education programs in most countries as such programs are either limited or only newly implemented in these regions. ${ }^{2}$ In addition, countries with a new epidemiological transition have reported a high proportion of early onset CRC. The younger population group is normally exempt from screening programs. ${ }^{1,3,4}$ Currently, CRC is the third most common cancer in men and the second most common cancer in women. There were an estimated 1.4 million new CRC cases and 693,900 deaths in $2012 .{ }^{5}$ Since mortality and survival rates are directly influenced by incidence, screening and detection rates, they are the best indication of successful treatment of cancer. ${ }^{6}$

The aim of this review is to examine the status of CRC incidence, screening and population-specific risk factors in low- and middle-income countries such as South Africa, India, Brazil and China. The situation in these countries will be compared to those in developed or high-income countries such as the United States of America and the United Kingdom. It will focus on the relationships between geographic area and the incidence and mortality of CRC. It will also examine the use of biological markers as prognostic or diagnostic markers of the disease. Finally, it will discuss the different risk factors of the disease in economically different countries.

\section{Methods}

Literature searches were performed in PubMed using the following search terms; colorectal cancer epidemiology; colorectal cancer incidence rate developed countries; colorectal cancer incidence rate low- and middle-income countries, colorectal cancer mortality developed countries, colorectal cancer mortality low- and middle-income countries, colorectal cancer Biomarkers colorectal cancer screening and colorectal cancer treatment. In order to obtain country-specific data, the search term colorectal cancer and the countries or geographical area name were used (USA, Europe, Asia, China, India, Sub-Saharan Africa, South Africa and Tanzania). In addition to this the following search terms were used; colorectal cancer geographic distribution, colorectal cancer ethnicity, colorectal cancer socioeconomic distribution, colorectal cancer international trends. The name of the country was used in combination with the search term colorectal cancer environmental risk factors, to obtain references for the risk factors for the population of these countries. Information on the genetic factors contributing to colorectal cancer in each country was obtained by combining the country name and the following search terms; colorectal cancer Genomewide association study, colorectal cancer non-coding mRNA and colorectal cancer Genetic polymorphisms. Cancer statistics for colorectal cancer were obtained from publications by the Surveillance, Epidemiology, and End Results (SEER) program and the World Health Organization (WHO). Data were also obtained from the GLOBOCAN database International Association of Cancer Registries (IACR).

\section{Cancer Geographic Variation}

The global distribution of CRC varies greatly between different geographic areas. As previously mentioned, CRC is most common in developed countries with a Western culture ${ }^{7}$ with the developed world accounting for more than $63 \%$ of all cases of CRC. ${ }^{8}$ The incidence rate varies up to 10 -fold between countries with the highest rates compared to those with the lowest rates. ${ }^{9}$ Geographic variations play an important role in the occurrence of new cancer cases; this is because occurrence and outcomes differ between racial and ethnic groups. This variation is due to inequalities in wealth, the variation that results from differences in risk factor exposures, barriers to high-quality cancer prevention, early detection and treatment. ${ }^{10-12}$ CRC ranges from more than 40 per 100 000 people in the United States, Australia, New Zealand and Western Europe to less than 5 per 100000 in Africa and certain parts of Asia. ${ }^{13}$ The high incidence of CRC in high-income countries and the lower incidence in low- and middle-income countries are shown in Table 1. Overall, CRC has the highest incidence and lowest mortality rates in high-income countries such as the United States of America and low incidence and high mortality rates in low- and middle-income countries such as African countries, India, Brazil and China. This is caused by the fact that the high-income countries have high standard of health care, whereas low- and middle-income countries struggle to fund healthcare facilities and screening programs. ${ }^{12}$ Casual analysis of incidence data seems to indicate that CRC incidence is higher in males than females; however, this is misleading as males develop colon cancer at a younger age with females having a similar lifetime risk catching up to males in later life. ${ }^{14}$

\section{Colorectal Cancer Mechanisms}

Multiple pathways have been reported to be involved in the pathogenesis of CRC. These include pathways 
Table I Estimated Incidence Rates from Low-Income and High-Income Countries in Both Males and Females in 2012 ${ }^{28}$ )

\begin{tabular}{|c|c|c|c|}
\hline \multirow[t]{2}{*}{ Region and Example Country } & \multicolumn{3}{|c|}{$\begin{array}{l}\text { Age Standardized Incidence } \\
\text { Rate (Cases per } 100,000)\end{array}$} \\
\hline & Males & Females & Both \\
\hline Australia/New Zealand & 44.8 & 32.2 & 38.5 \\
\hline Australia & 41.9 & 32.4 & 36.9 \\
\hline South Europe & 39.5 & 24.1 & 31.8 \\
\hline Italy & 36 & 24.8 & 29.9 \\
\hline Western Europe & 39.1 & 24.9 & 32 \\
\hline France & 30.4 & 36.9 & 24.8 \\
\hline UK & 37.8 & 27 & 32.1 \\
\hline Northern Europe & 36.5 & 25.3 & 30.9 \\
\hline Norway & 46.9 & 39.3 & 42.9 \\
\hline Central and Eastern Europe & 34.5 & 21.7 & 28.1 \\
\hline Hungary & 70.6 & 36.8 & 51.2 \\
\hline Northern America & 30.1 & 22.7 & 26.4 \\
\hline US & 28.8 & 22.6 & 25.6 \\
\hline Eastern Asia & 22.4 & 14.6 & 18.5 \\
\hline Russia & 32.9 & 23.1 & 26.7 \\
\hline South America & 17.1 & 14.6 & 15.8 \\
\hline Brazil & 21.6 & 18.1 & 19.6 \\
\hline South-Eastern Asia & 15.2 & 10.2 & 12.7 \\
\hline Thailand & 17.6 & 13.9 & 15.5 \\
\hline Southern Africa & 14.2 & 8.7 & 11.5 \\
\hline South Africa & 18.1 & 12 & 14.4 \\
\hline Central America & 8.8 & 7.1 & 8.0 \\
\hline Mexico & 12.5 & 10 & 11.2 \\
\hline Northern Africa & 8.5 & 6.9 & 7.9 \\
\hline Tunisia & 13 & 11 & 11.9 \\
\hline Eastern Africa & 7.1 & 6.1 & 6.6 \\
\hline Tanzania & 7.4 & 10.4 & 9 \\
\hline Western Africa & 4.5 & 3.8 & 4.2 \\
\hline Nigeria & 6.8 & 5.6 & 6.2 \\
\hline Eastern Asia & 22.4 & 14.6 & 18.5 \\
\hline Japan & 49.1 & 29.6 & 38.9 \\
\hline South-Central Asia & 7.0 & 5.2 & 6.1 \\
\hline China & 28.1 & 19.4 & 23.7 \\
\hline India & 5.8 & 3.1 & 4.4 \\
\hline
\end{tabular}

Note: Data from Torre et al 2015. ${ }^{28}$

involved in abnormal DNA methylation, the control of gene expression through microRNA (miRNA) and the CIN pathway. Alterations in these pathways may develop through the involvement of CRC risk factors. The genes that encode for the proteins that are involved in these pathways may contain mutations that are involved in CRC. Table 2 represents the proteins involved in CRC and they serve as molecular markers for CRC. ${ }^{15}$ The initial step leading to colorectal carcinogenesis is thought to be the development of aberrant crypt foci (ACF). The
Table 2 Colorectal Cancer Molecular Markers and Implications for Disease Behavior

\begin{tabular}{|c|c|c|}
\hline Gene & Disease Effect & Reference \\
\hline $\begin{array}{l}\text { sTNFR-2 } \\
\text { expression }\end{array}$ & $\begin{array}{l}\text { Increased development of CRC, } \\
\text { and lower risk of those taking } \\
\text { aspirin }\end{array}$ & [78] \\
\hline Interleukin-6 & $\begin{array}{l}\text { Increased development of CRC } \\
\text { and advanced CRC stage and } \\
\text { worse prognosis }\end{array}$ & [79-8I] \\
\hline $\begin{array}{l}\text { C-reactive } \\
\text { protein }\end{array}$ & $\begin{array}{l}\text { This gene is associated with CRC } \\
\text { increased risk, in lean individuals }\end{array}$ & {$[78,82]$} \\
\hline $\operatorname{miR}-2 I$ & $\begin{array}{l}\text { Poor prognosis in patients with } \\
\text { stage IV CRC }\end{array}$ & [48] \\
\hline$m i R-203$ & $\begin{array}{l}\text { Poor survival among Caucasians } \\
\text { with stage IV and poor survival in } \\
\text { Blacks with stages I and II CRC }\end{array}$ & [48] \\
\hline CIMP-High & $\begin{array}{l}\text { Low colon cancer-specific } \\
\text { mortality }\end{array}$ & [83] \\
\hline BRAF V600E & High cancer-specific mortality & [84] \\
\hline $\begin{array}{l}\text { Cyclin DI } \\
\text { overexpression }\end{array}$ & $\begin{array}{l}\text { Low colon cancer and overall } \\
\text { mortality }\end{array}$ & [83] \\
\hline MSI & $\begin{array}{l}\text { Better prognosis and survival than } \\
\text { CIN/MSS }\end{array}$ & {$[85,86]$} \\
\hline $\begin{array}{l}\text { Cathepsin } \\
\text { B expression }\end{array}$ & $\begin{array}{l}\text { High colorectal cancer and overall } \\
\text { mortality }\end{array}$ & [87] \\
\hline HIFI & $\begin{array}{l}\text { High colorectal cancer-specific } \\
\text { mortality }\end{array}$ & [88] \\
\hline $\begin{array}{l}\text { Line-I } \\
\text { Hypomethylation }\end{array}$ & $\begin{array}{l}\text { Young age of onset and increased } \\
\text { cancer and overall mortality }\end{array}$ & {$[88,89]$} \\
\hline $\begin{array}{l}\text { PI3KCA } \\
\text { mutations }\end{array}$ & $\begin{array}{l}\text { Increased survival among chronic } \\
\text { aspirin users }\end{array}$ & [90] \\
\hline $18 q$ & $\begin{array}{l}\text { Loss in non MSI } \rightarrow \text { decreased } \\
\text { survival } \\
\text { No loss } \rightarrow 5 \text {-year survival } 96 \%\end{array}$ & {$[85,91]$} \\
\hline $\begin{array}{l}\text { COX-2-positive } \\
\text { tumors }\end{array}$ & $\begin{array}{l}\text { Increased cancer specific } \\
\text { mortality }\end{array}$ & [91] \\
\hline p53 expression & Better survival among non-obese & [92] \\
\hline P-AMPK & $\begin{array}{l}\text { Better survival among } \mathrm{P} \text {-ERK } \\
\text { positive }\end{array}$ & [25] \\
\hline $\begin{array}{l}\text { K-ras cod. } 12 \\
\text { mutation }\end{array}$ & $\begin{array}{l}\text { Metastatic disease; poor } \\
\text { prognosis; increased cancer } \\
\text { specific mortality }\end{array}$ & {$[24,93]$} \\
\hline $\begin{array}{l}\text { CDK8 } \\
\text { overexpression }\end{array}$ & Poor prognosis & [94] \\
\hline
\end{tabular}




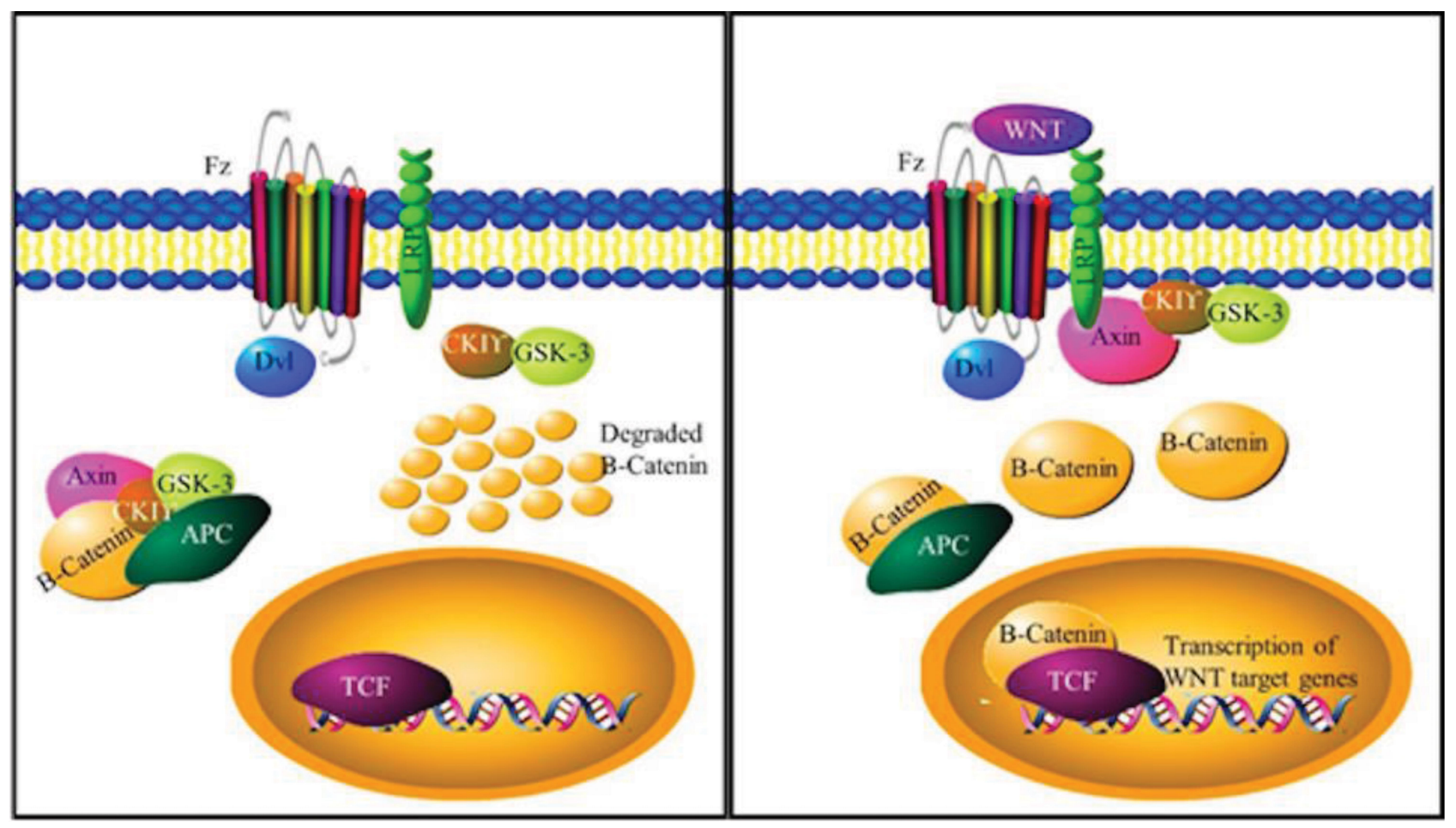

Figure I The Wnt signalling pathway. Wht signalling leads to the prevention of $\beta$-Catenin. The destruction complex composed of APC, GSK, Axin and CKI carries out the destruction of $\beta$ Catenin. Wnt signalling leads to the destabilisation of the destruction complex and the sequestering of certain components of the complex.

activation of the WNT pathway happens during ACF resulting from inactivating mutations in the adenomatous polyposis coli (APC) gene. Activation of KRAS mutations and loss of TP53 expression usually mediate the progression to adenoma and carcinoma. Adenoma progresses due to mutations in PIK3CA and loss of 18q. ${ }^{16}$ Figure 1 represents the sequence of molecular events that occur during the progression of adenoma-carcinoma.

\section{CIN Pathway}

\section{The WNT Signaling Pathway}

$\mathrm{CIN}$ is the pathway most commonly associated with CRC. It is well characterized and involves different mitotic spindle checkpoint regulators and proteins; this may influence mitotic chromosomal stability. ${ }^{17,18}$ The mutation of the $A P C$ tumor suppressor gene is the initial course; this involves both sporadic and germline mutation in familial Adenomatous Polyposis (FAP). ${ }^{19,20}$ FAP syndrome is an autosomal dominant genetic disorder leading to the development of adenomas in the colon or rectum during adolescence and early adulthood. It has been reported that there is a germline mutation of the $A P C$ gene found in $60-80 \%$ of families with FAP. ${ }^{15,21}$ FAP is characterized by less than 100 adenomas and develops with APC germline mutations involving the $5^{\prime}$ or $3^{\prime}$ region of the gene. The phenotypes of FAP and MUTYH-associated polyposis (MAP) are similar. MUTYH is a glycosylase involved in the base excision repair pathway involved in the repair of DNA damaged by oxidative stress. ${ }^{15,22}$ The $A P C$ tumor suppressor gene is involved in the APC $/ \beta$-Catenin/Tcf pathway. APC is a negative regulator of $\beta$-Catenin and degrades $\beta$-Catenin. It also interacts with E-cadherin where it promotes cell adhesion. Failure to degrade $\beta$-Catenin cytoplasmic accumulation activates and increases the WNT pathway (Figure 1) ${ }^{23}$ signaling. This may lead to translocation into the nucleus where it stimulates TCF-targets with increased proliferation, differentiation, migration and adhesion of colorectal cells. Mutations in genes implicated in APC/ $\beta$-Catenin/Tcf pathway in CRC lacking $A P C$ mutations are also found in sporadic $\mathrm{CIN}$ tumors. $^{23}$

\section{RAS Pathway}

The transition from adenoma to carcinoma is led by the $K$-Ras gene, a proto-oncogene that encodes for a GTPase protein, which is involved in the transduction and propagation of extracellular signals such as mitogen-activated protein kinase (MAPK). Mutation of K-Ras may lead to a permanently active state that allows the cells to evade apoptosis and undergo rapid and uncontrolled proliferation 


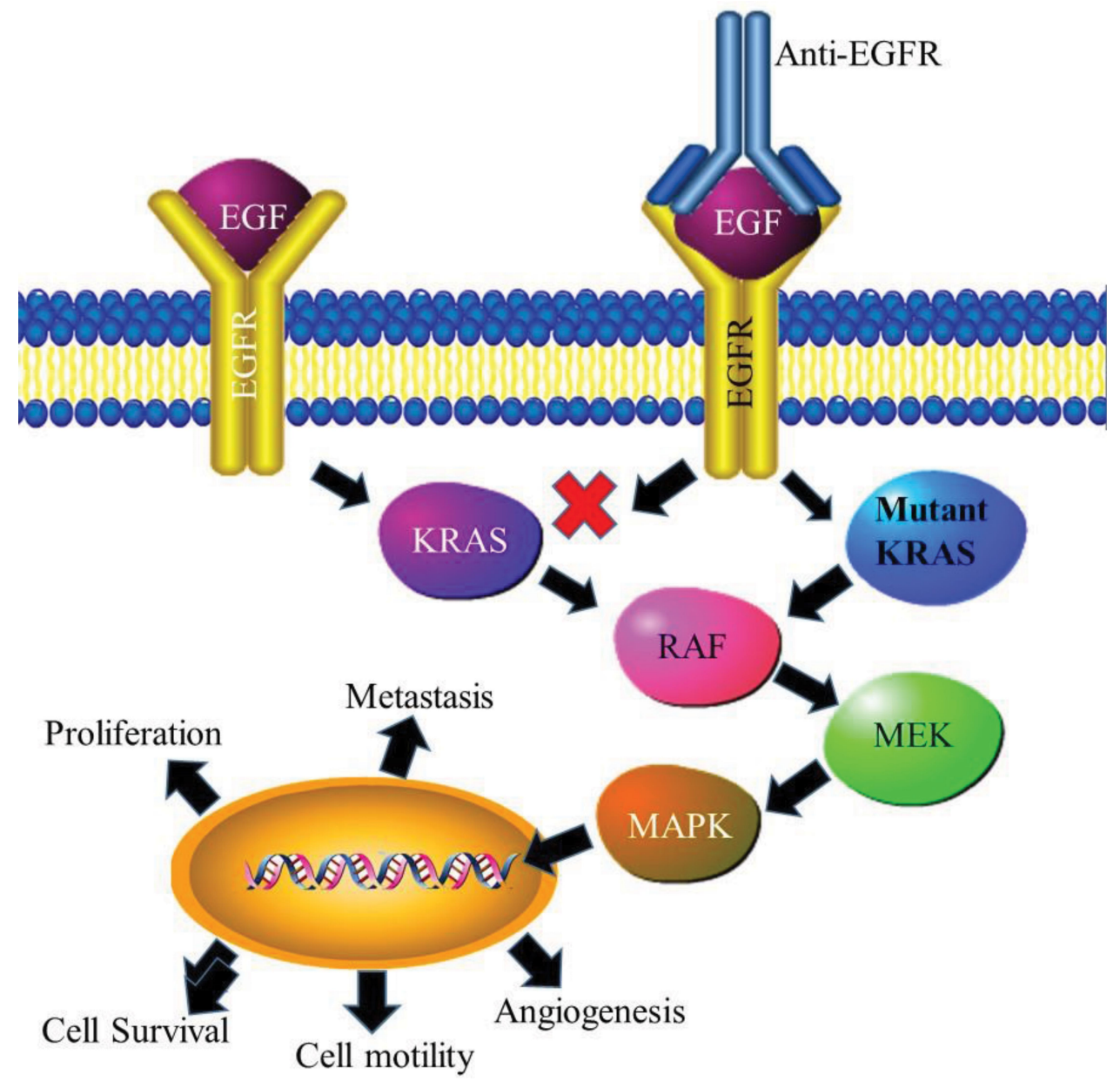

Figure 2 K-RAS pathway in cancer development. Mutant K-Tas remains in a permanently active state, which in turn leads to the permanent activation of MAPK signalling. As a result, cells in this state are able to avoid apoptosis and undergo rapid, uncontrolled cell division.

(Figure 2). ${ }^{21}$ The presence of mutations in codons 12 and 13 of $K$-Ras in patients with CRC can be used as a prognostic marker to evaluate outcomes and to indicate the best chemotherapeutic strategies. The KRAS pathway is also involved with other signals that are critical for the initiation of carcinogenesis (Figure 3) ${ }^{16}$ It was also demonstrated that high WNT activity was connected with increased MAPK signaling in KRAS mutated CRC samples. ${ }^{24}$ Other studies

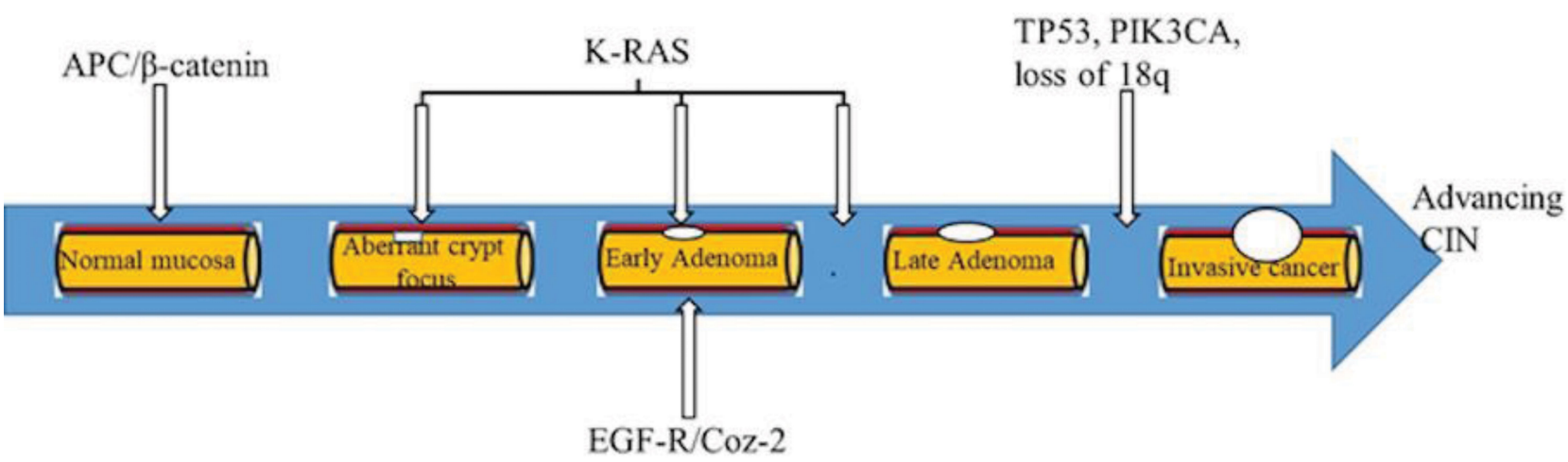

Figure 3 The sequence of adenoma-carcinoma development: Step wise that lead to invasive cancer. A representation of various gene mutations and molecular changes that lead to colon cancer. Various genetic changes play different roles at different stages of cancer progression. 
show interaction between the AMP-activated protein kinase (AMPK) and MAPK. AMPK is a cellular energy balance status sensor that plays a role in the regulation of cell proliferation and growth through the inhibition of the mTOR pathway and activation of the CDKN1A (p21) and p53 pathways. Increase in the expression of phosphorylatedAMPK is, therefore, associated with a good prognosis among p-ERK-activated CRC patients. ${ }^{25}$

\section{Colorectal Cancer Incidence Rate}

Worldwide, the incidence and trends in CRC diagnosis vary. In many areas where there were historically low rates, such as Latin America and Asia, the incidence rates are increasing. Table 2 represents incidence rate of $\mathrm{CRC}$ in both genders worldwide.

\section{High-Income Countries}

In 2015 the highest recorded incidence rates in the world occur in Eastern Europe and studies indicate that the incidence in this area is on the rise. As of 2015, highincome countries generally have a higher incidence of CRC but in some of these countries such as the United States, United Kingdom, New Zealand and France, the incidence rate is decreasing. In other high-income countries such as Canada and Australia, the incidence rates are relatively stable. This decrease in incidence rates in some high-income countries is largely attributed to an improvement in the level of screening and implementation of screening programs. Screening programs have also made use of more accurate fecal blood screening tests. Improved treatment in the form of, removal of precancerous lesions and a reduction in CRC risk factors such as smoking, which has also been reported to contribute to decrease in other countries have also contributed to decreased CRC incidence and CRC associated mortality. ${ }^{26-28}$ High-income countries are where the majority of randomized, controlled trials and observational studies have been performed Most of the highincome countries that have screening programs use the more advanced Fecal Immunochemical test (FIT) (see Table 3). In the United States a multiple test risk, and age program has been established, which encourages the average risk population to undergo annual FIT screening from the age of 50, a multitarget DNA test every 3 years and a colonoscopy every 10 years. ${ }^{29}$ Another alarming trend in CRC incidence rates reported in some highincome countries, such as the United States, is the increase in incidence among adults younger than 50 years. Screening in these individuals is not recommended. ${ }^{27,30}$ The reasons for this increase are not yet known. The decrease in mortality rates for CRC may be due to improvements in screening and treatment. ${ }^{26,27}$ In the USA, the main risk factors for colorectal cancer are Inflammatory bowel disease, familial history of CRC, lack of regular physical activity, a diet low in fruit and vegetables, a low-fiber and high-fat diet, or a diet high in processed meats, obesity, alcohol consumption and tobacco use. $^{26}$

\section{Low- to Middle-Income Countries}

The incidence rate of CRC is increasing in Latin America, Asia and Eastern Europe. This is most likely due to a rapid change in diet, activity patterns and increased smoking for several decades. ${ }^{31-33}$ In low-income countries, such as Brazil, India and parts of Africa, the incidence of CRC is on the rise. These increasing CRC rates combined with fewer resources for the screening, prevention and treatment of the disease lead to increasing mortality rates. ${ }^{26,32}$ In Zimbabwe diabetes was identified as a risk factor associated with the development of colon cancer. Current or previous infection with the Schistosomiasis parasite was also found to increase the risk of developing colon cancer in African countries. ${ }^{34}$

\section{Sub-Saharan Africa: Tanzania and South Africa}

Studies reporting the incidence rates of CRC have been previously performed. In 2012, the incidence rates in 19 Sub-Saharan countries were analyzed. This study established that South Africa with an Age Standardized incidence Rate (ASR) in 2018 of 14.4 and Zimbabwe (ASR in 2018 of 10.1) had the highest recorded incidence of CRC in Sub-Saharan Africa. ${ }^{35}$ In comparison to South Africa, Tanzania has a much lower incidence rate of CRC (approximately 9.0 in 2018). ${ }^{5,35}$

In South Africa, the incidence was highest in the White population followed by those of Asian ancestry and then the mixed ancestry population group. The population group with the lowest incidence is the Black population. However, in Sub-Saharan Africa, the incidence of $\mathrm{CRC}$ in the Black population is on the rise. ${ }^{36}$ Moreover, $\mathrm{CRC}$ in the Black population occurs at a much younger age compared to their white counterparts ${ }^{35}$ and South Africa mirrors this trend. ${ }^{36,37}$ South Africa shows marked differences in screening, treatment and surviving CRC based on racial, gender, provincial, and urban-rural divides. ${ }^{38}$ South Africa also lacks a national CRC 
Table 3 Screening Programs and Their Effectiveness in Various Countries

\begin{tabular}{|c|c|c|c|c|c|}
\hline Country & Technique & $\begin{array}{l}\text { Dates of } \\
\text { Data }\end{array}$ & $\begin{array}{l}\text { Ages of Target } \\
\text { Patients }\end{array}$ & Participation & $\begin{array}{l}\text { Detection } \\
\text { Rate }\end{array}$ \\
\hline Spain & FIT & 2014 & $50-69$ & $49.2 \%$ & 2.75 per 1000 \\
\hline France & G-FOBT since 20,008 & in 2008 & $50-74$ years & $34.3 \%$ & $7.5 \%$ \\
\hline Ireland & FIT & & 50 to 74 years & $51 \%$ & $0.33 \%$ \\
\hline Italy & $\begin{array}{l}\text { FIT between 2005-2006 } \\
\text { Since } 2009\end{array}$ & $\begin{array}{l}2006 \\
2009\end{array}$ & $50-69$ & & $\begin{array}{l}4 \% \\
5 \%\end{array}$ \\
\hline Lithuania & FIT since 2009 & $2009-2012$ & 50 to 74 & $46 \%$ & $3.1 \%$ \\
\hline Croatia & G-FOBT since 2007 & 2007 & $50-74$ & $19.9 \%$ & $3.8 \%$ \\
\hline England & G-FOBT since 2006 & 2010 & 60 to 69 & $\begin{array}{l}49.6 \% \text { of men and } 54.4 \% \text { of } \\
\text { women }\end{array}$ & $2 \%$ \\
\hline Slovenia & FIT since 2009 & 2014 & 50 to 69 & $57.8 \%$ & $2.12 \%$ \\
\hline $\begin{array}{l}\text { Czech } \\
\text { Republic }\end{array}$ & $\begin{array}{l}\text { G-FOBT } 200-2008 \\
\text { FIT since } 2009\end{array}$ & 2010 & Older than 50 & $22.7 \%$ & \\
\hline Canada & $\begin{array}{l}\text { FIT and G-FOBT } \\
2009-2011\end{array}$ & $2009-2011$ & $50-74$ & $16.1 \%$ & 1.8 per 1000 \\
\hline Thailand & FIT since $20 \mathrm{II}$ & & $50-65$ & $62.9 \%$ & $1.1 \%$ \\
\hline Taiwan & 2004 & & $50-69$ & $21.4 \%$ & 4.6 per 1000 \\
\hline South Korea & FIT since 2004 & 2008 & & $21.1 \%$ & \\
\hline Japan & FIT since 1992 & 2013 & $40-69$ & $\begin{array}{l}41.4 \% \text { in men } \\
34.5 \% \text { in women }\end{array}$ & \\
\hline Australia & FIT between 2002 to 2006 & 2006 & $55-74$ years & $45.4 \%$ women $47.4 \%$, men & $\begin{array}{l}9 \% \text { of } \\
\text { participants }\end{array}$ \\
\hline
\end{tabular}

Notes: Details of screening programs in high-income countries. Data from Navarro et al. ${ }^{29}$

screening program. Its public healthcare system also has a limited ability to provide proper diagnosis and treatment programs for CRC. ${ }^{39}$

Despite the incidence of CRC being historically very low in Tanzania, studies undertaken in the period, 2006-2016, show the incidence of colon cancer in Tanzania increased six-fold. Over half of the patients diagnosed in this period gave Dar es Salaam as their home. There was no difference between the incidence rates in males or females. Most patients were between the ages of 40 and $65 .{ }^{40}$

\section{Asia: India and China}

Risk factors for developing colon cancer in Asia were determined to be familial history, ethnicity, age, gender height; smoking, alcohol consumption, weight, whether they have a westernized diet, engage in physical activity, have certain chronic diseases and differences in their microbiota. $^{41}$

\section{India}

India has an ASR of 4.4 per $100000 .{ }^{5}$ There is very little information on the state of CRC in India. As such multiple studies have been conducted on representative groups of patients at various hospitals. ${ }^{42}$ One of the major findings of these studies is the younger age of diagnosis in India compared to higher income countries. In these studies, the mean age of diagnosis was 49 . Most patients were diagnosed at Stage III or IV (ranging from 54-79\%) with very few being diagnosed at stage I ${ }^{42,43}$ Noronha et al showed that $41 \%$ of patients exhibit signs of metastatic spread with the liver being the most common site of invasion. ${ }^{42}$ Having a curative outcome as the end goal, the majority of these patients were surgically treated with adjuvant 
chemotherapy. However, the only treatment available to a large percentage of patients was palliative or supportive treatments. The result of treatment in these studies was very positive with the vast majority of stage II patients surviving for 5 years post diagnosis. This number drops drastically for those patients diagnosed at stage IV. ${ }^{42,43}$

\section{China}

The incidence of CRC in China is 23.3 per $100000 .^{5}$ An analysis of the changing trends in CRC incidence was conducted over a twenty-year period (1981-2000) in the city of Tianjin. In this twenty-year period 4954 cases of CRC were recorded, of this $51.4 \%$ were male and $49.6 \%$ were female. Most of these patients were between the ages of 55-79 with the average age at diagnosis being 62 . The incidence rate increased steadily over the twenty-year period from 1981-2000. ${ }^{44}$ Unsurprisingly, in terms of mortality from CRC, the highest percentage of deaths recorded was in the age group with the highest incidence (55-79). The total mortality was 2147 of the 4954 patients with the mortality rate increasing over the period examined. ${ }^{45}$ During the twenty-year period, the average age of diagnosis and death showed an increasing trend. ${ }^{44,45}$ Since the 1970 s, the CRC incidence rates have also increased in Shanghai. ${ }^{46}$ The Jiashan county in the north of Zhejiang Province has the highest incidence of colon cancer in China. ${ }^{47}$ Other risk factors that have been identified in China included the use of oral contraceptives, progesterone injections during pregnancy, induced abortions, ${ }^{46}$ psychological depression, negative emotion and lower digestive tract diseases. ${ }^{47}$

\section{Colorectal Risk Factors}

$\mathrm{CRC}$ is considered to be one of the major cancers for which modifiable causes may be identified and prevented. The disease is associated with a wide range of cultural and social factors. ${ }^{48,49} \mathrm{CRC}$ can be prevented through minimizing the exposure of an individual to these risk factors by living a healthy lifestyle. This includes avoiding the use of tobacco and alcohol, maintaining a healthy body weight, physical activities, a diet low in red and processed meats and high in fiber. ${ }^{28}$ Evidence for the contribution of environmental risk factors to the development of CRC comes from studies of migrants and their offspring. In 2007 individuals migrating from low- to high-risk countries showed an increase in the rates of CRC typical of the population of the host country. ${ }^{8,49}$

\section{Nutritional Practices}

One of the risk factors that is suspected to be driving these increases in CRC incidence is changes in diet. Diet influences the change in CRC risk. Having a healthier diet may reduce the risk of developing CRC by $70 \%{ }^{50}$ By tracking the dietary habits of some CRC patients compared to healthy individuals, it was established that certain foods and eating habits may contribute to CRC development. ${ }^{46}$ Some of these risk foods include high levels of red meat, pork, animal oils, fish and eggs. ${ }^{46,47}$ The consumption of preserved foods led to a higher risk of developing CRC. ${ }^{46}$ Diets that are high in fat, especially animal fat, represent the largest diet-related CRC risk. ${ }^{7}$ High-fat diets with high levels of meat consumption are linked to the concept of the typical Western diet. The Western diet has been associated with colorectal carcinogenesis. ${ }^{51,52}$ Meat consumption is mostly associated with colon cancer than rectal cancer. ${ }^{51}$ The mechanisms underlying the consumption of high levels of red meat contributing to the development of CRC may involve the presence of heme iron in red meat. ${ }^{52,53}$ An increased intake of dietary fiber may dilute fecal content, increase fecal bulk and reduce transit time of waste leading to lower levels of CRC risk. The presence of high levels of dietary fiber has been proposed as one of the main differences between the rates of CRC between Africa and Westernized countries. ${ }^{13}$ Food that lowers the risk of developing CRC include fresh fruits and vegetables, increased fiber and micro-nutrients such as vitamin $\mathrm{C}$, carotene, and vitamin E. ${ }^{46,47}$

\section{Physical Activity and Obesity}

Physical inactivity and excess body weight are the third and fourth largest contributors, respectively, to the risk of developing CRC. There is abundant evidence that high overall levels of physical activity are associated with a lower risk of CRC. The frequency and intensity of physical activity are inversely associated with CRC risk. $^{54,55}$ Regular physical activity in combination with a healthy diet were shown to decrease the risk of CRC. This effect was more noticeable for colonic than for rectal disease. $^{13,56}$ The biological mechanisms underlying this relationship between reduced physical activity and CRC are yet to be elucidated. Moderate physical activity raises the metabolic rate and increases maximal oxygen uptake. ${ }^{54}$ Studies have also shown that individuals who use energy more efficiently may have a lower risk of developing CRC. $^{7}$ 
The mechanisms behind obesity-linked colorectal cancer risk have been partly explained through IGF-1 activity as well as hyperinsulinemia/insulin resistance. Epidemiological studies have shown that type II diabetes is a risk factor leading to an increased risk for developing colorectal cancer. Type 2 diabetes has been shown to cause a consistent elevation in the risk. ${ }^{57}$ Insulin-like growth factors (IGFs) play a role in the development of various cancers, since IGF plays a role in growth and development, and along with specific IGF receptors, are overexpressed in cancer cells. IGF accomplishes this by promoting cell cycle progression and inhibiting apoptosis. ${ }^{58}$ Insulin promotes cancer through the stimulation of insulin receptors and a reduction in the levels of IGF binding proteins. This results in increased levels of free unbound IGF. This leads to downstream activation of pathways such as the phosphatidylinositol 3-kinase (PI3K)AKT - mammalian target of rapamycin (mTOR) pathway and the Ras-Raf-MEK- Mitogen-Activated Protein Kinase (MAPK) pathway. Both of which regulate cell growth and proliferation. Increased insulin signaling also results in higher metabolic activity within the cell leading to increased oxidative stress and DNA damage (Reviewed in $^{59}$ ). Cancer cells rely upon higher rates of glycolysis and are in need of constant high levels of glucose. This is supplied in higher amounts in patients suffering from hyperglycemia as a result of diabetes. ${ }^{60}$

The lowest income countries also show low levels of obesity and have the lowest incidence of CRC. Japan's High CRC incidence is not accompanied by high levels of obesity. China also shows low levels of obesity in comparison to the levels of obesity observed in the country (Table 4). These observations show that while obesity contributes to the incidence of CRC it is influenced by other risk factors.

\section{Tobacco Use}

It is estimated that $12 \%$ of CRC mortalities are linked to smoking and tobacco use. ${ }^{61}$ Carcinogens identified in tobacco have been shown to increase the growth of colon and rectal tumors and are associated with an increased risk of developing CRC. ${ }^{62}$ Cigarettes have been shown to increase the formation and growth rate of adenomatous polyps, the precursor lesions of CRC. ${ }^{63,64}$ Tobacco consumption over long periods of time is associated with larger polyps in the colon and rectum. Smokers also

Table 4 Risk Factors for CRC in Different Countries Ranked by CRC Incidence

\begin{tabular}{|c|c|c|c|c|c|c|}
\hline \multirow[t]{2}{*}{ Country } & \multirow[t]{2}{*}{$\begin{array}{l}\text { CRC Incidence } \\
\text { Rank }\end{array}$} & \multicolumn{2}{|c|}{ Obesity in $2013^{95}$} & \multicolumn{2}{|c|}{$\begin{array}{l}\text { Tobacco Use \% of } \\
\text { Population }{ }^{96} 2015\end{array}$} & \multirow{2}{*}{$\begin{array}{l}\text { Alcohol Use } \\
\text { Average Daily Intake in } \\
\text { Grams of Pure Alcohol }\end{array}$} \\
\hline & & Kj per Capita & Rank in World & Males & Females & \\
\hline Hungary & I & 14,520 & 41 & 32 & 24.8 & 37 \\
\hline Norway & 2 & 14,430 & 67 & 22.4 & 22.1 & 20.4 \\
\hline Japan & 3 & $\mathrm{II}, 720$ & 185 & 33.7 & 10.6 & 30.4 \\
\hline Australia & 4 & 13,470 & 27 & 16.7 & 13.1 & 28.9 \\
\hline UK & 5 & 14,430 & 33 & 19.9 & 18.4 & 33.7 \\
\hline Italy & 6 & 15,270 & 100 & 28.3 & 19.7 & 25.9 \\
\hline Russia & 7 & 13,890 & 67 & 59 & 22.8 & 43.5 \\
\hline USA & 8 & 15,900 & 12 & 19.5 & 15 & 29.6 \\
\hline France & 9 & 14,770 & 87 & 29.8 & 25.6 & 36.1 \\
\hline China & 10 & 12,510 & 168 & 47.6 & 1.9 & 27.9 \\
\hline Brazil & 11 & 13,050 & 81 & 19.3 & 11.3 & 41.7 \\
\hline Thailand & 12 & 10,630 & 140 & 41.4 & 2.3 & 43.1 \\
\hline South Africa & 13 & 12,550 & 30 & 31.4 & 6.5 & 64.6 \\
\hline Tunisia & 14 & 13,930 & 40 & No data & No data & 79.1 \\
\hline Mexico & 15 & 13,640 & 28 & 20.8 & 6.6 & 33.1 \\
\hline Tanzania & 16 & 8453 & 153 & 27.5 & 3.8 & 55.7 \\
\hline Nigeria & 17 & $1 \mathrm{I}, 340$ & 145 & 17.4 & 0.2 & 55 \\
\hline India & 18 & 2360 & 187 & 20.4 & 1.9 & 31.5 \\
\hline
\end{tabular}

Notes: $\mathrm{E}$ shows eighteen countries that are ranked by their CRC incidence from I to I8. This is accompanied by the risk factors of alcohol, tobacco and obesity for each country. Compared to other middle- to low-income countries. The highest incidence rate was found in the high-income countries. The first two show a high level of obesity. The third, Japan, has a high percentage of tobacco use. Middle- and low-income countries are found at the bottom of the table and show low levels of obesity and tobacco use but high levels of alcohol consumption. 
show an earlier average age of onset for CRC among men and women who smoke cigarettes. ${ }^{61,65}$

Table 4 shows the contribution of risk factors such as tobacco use to the incidence of CRC. The lowest income countries with the lowest incidence of CRC also show comparatively low levels of tobacco use. The first three high-income countries with high levels of CRC also show high levels of tobacco usage. Russia which shows very high levels of tobacco use only shows moderately high levels of CRC incidence.

\section{Alcohol Consumption}

The regular consumption of alcohol is associated with the increase of risk of developing CRC. Alcohol consumption is also associated with an increase in the early onset of $\mathrm{CRC}$ as well as a disproportionate increase of tumors in the distal colon. ${ }^{56,61,65}$ The reactive metabolites of alcohol, such as acetaldehyde, can be carcinogenic. A social relationship between alcohol consumption and smoking also exists. ${ }^{61}$ Alcohol and tobacco may act together to increase the incidence of CRC as tobacco may induce mutations in DNA that are less efficiently repaired in the presence of alcohol. Alcohol may sometimes act as a solvent to enhance the penetration of other carcinogenic molecules into mucosal cells. ${ }^{66}$ The effects of alcohol may also be mediated through the production of prostaglandins, lipid peroxidation and generation of free radical oxygen species. ${ }^{61,67}$ Table 4 shows the level of alcohol consumption related to $\mathrm{CRC}$ incidence. The selected countries show very little association between alcohol consumption and $\mathrm{CRC}$ incidence.

\section{Colorectal Cancer Prevention}

CRC preventive measures involve reducing the exposure to the risk factors mentioned previously. ${ }^{63,68}$ Early screening to detect colorectal polyposis is advisable as early detection is associated with a better prognosis. Several screening options are available, such as the guaiac-based fecal occult blood test (FOBT), the immunochemical FOBT, flexible sigmoidoscopy, stool DNA test, computed tomography colonography, and colonoscopy. However, some of these screening options require skilled technicians', are expensive, less convenient and have greater risks for patients compared with other tests. ${ }^{69}$ Some of these screening options may not be available in low- and middle-income countries since they have economic constraints. Colonoscopy is the gold standard method of screening. It is sensitive, reliable and allows for the treatment of precancerous lesions. The use of colonoscopies to screen patients can result in up to an $88 \%$ decrease in cancer mortality. However, it is expensive and requires highly trained staff with the sedation of the patient. Incorrectly performed or incomplete colonoscopy led to less than a $47 \%$ reduction in cancer mortality. ${ }^{70}$ The Guardiac-based fecal occult test (gFOBT) functions by detecting blood in the feces by detecting peroxidase activity of heme. It has the advantages of being cheap. The use of the test was found to lower cancer-based mortality over a ten-year period by between $18 \%$ and $22 \%$ when the test was performed every two years over this ten-year period. However, the test can be influenced by the diet and is therefore, not very specific and has a low predictive value. ${ }^{71}$ It is therefore a test that should only be used if no other options are available. The fecal immunochemical test (FIT) is the test that will most likely replace gFORT. It is based on the use of an antibody to human globin, so it is not affected by the diet. It requires less samples than gFORT and is more sensitive. ${ }^{72}$ Another more advanced fecal blood test is the Multitarget stool DNA test. (MTsDNA). This test was found to be even more sensitive than FIT and has been adapted as a regular test in the US and relies on the detection of abnormal DNA within stool samples. FOBT is cost-effective and easy to perform, it is therefore, performed in many parts of the world. ${ }^{73}$ However, population-based CRC screening programs may not be viable in some developed countries where incidence of the disease is not sufficiently high to merit screening programs. ${ }^{74}$ On the other hand, it is advisable for developing countries to institute an affordable screening program as these countries have a growing and aging population, living an increasingly westernized lifestyle. Thailand initiated a pilot screening program in 2012 using FIT screening to screen the population aged between 50-65. This program was initiated in Lampang Province and the participation rate was $63 \%$ in females and $58 \%$ in males. Any positive FIT tests were followed up by colonoscopies. ${ }^{75}$ In Chile, a screening program was tested between 2007 and 2009 and found that 4938 people participated in the program. This was $77 \%$ of all eligible participants. FIT testing was used and only patients older than 50 were screened. ${ }^{76}$ There are no organized screening programs in any African country. In South Africa, there is a lack of facilities in the rural areas and in the mid-2010s a pilot study using a mobile screening facility was found to improve survival. ${ }^{77}$ 


\section{Conclusion}

Globally, CRC is a significant health and economic burden. It is expected to increase as populations grow and age in conjunction with the adoption of the western lifestyle. Economically less developed countries such as African countries, Brazil, India and China with historically low rates are experiencing an increased frequency of CRC. Genes responsible for the most common forms of inherited $\mathrm{CRC}$ have been identified and studied. However, research that is more extensive is required to identify remaining candidate genes that may be used as diagnostic or prognostic biomarkers. CRC burden can be controlled through the widespread application of existing knowledge such as reducing smoking, vaccination, early detection and promoting physical activity accompanied by a healthy diet. Our increased understanding of molecular mechanisms/ events underlying CRC carcinogenesis will enable the development of new targeted therapies and the discovery and application of new clinical biomarkers.

\section{Acknowledgment}

We would like to thank the South African Medical Research Council for funding this work.

\section{Disclosure}

The authors report no conflicts of interest in this work.

\section{References}

1. Bishehsari F, Mahdavinia M, Vacca M, Malekzadeh R, MarianiCostantini R. Epidemiological transition of colorectal cancer in developing countries: environmental factors, molecular pathways, and opportunities for prevention. World $J$ Gastroenterol. 2014;20 (20):6055-6072. doi:10.3748/wjg.v20.i20.6055

2. Gellad ZF, Provenzale D. Colorectal cancer: national and international perspective on the burden of disease and public health impact. Gastroenterology. 2010;138(6):2177-2190. doi:10.1053/j. gastro.2010.01.056

3. Isbister WH. Colorectal cancer below age 40 in the Kingdom of Saudi Arabia. Aust N Z J Surg. 1992;62(6):468-472. doi:10.1111/j.14452197.1992.tb07227.x

4. Veruttipong D, Soliman AS, Gilbert SF, et al. Age distribution, polyps and rectal cancer in the Egyptian population-based cancer registry. World J Gastroenterol. 2012;18(30):3997-4003. doi:10.3748/wjg. v18.i30.3997

5. Bray F, Ferlay J, Soerjomataram I, Siegel RL, Torre LA, Jemal A. Global cancer statistics 2018: GLOBOCAN estimates of incidence and mortality worldwide for 36 cancers in 185 countries. CA Cancer J Clin. 2018;68(6):394-424. doi:10.3322/caac.21492

6. Lam WK, White NW, Chan-Yeung MM. Lung cancer epidemiology and risk factors in Asia and Africa. Int J Tuberc Lung Dis. 2004;8 (9):1045-1057.

7. Boyle P, Langman JS. ABC of colorectal cancer: epidemiology. BMJ. 2000;321(7264):805-808. doi:10.1136/bmj.321.7264.805
8. Janout V, Kollarova H. Epidemiology of colorectal cancer. Biomed Pap Med Fac Univ Palacky Olomouc Czech Repub. 2001;145 (1):5-10. doi:10.5507/bp.2001.001

9. Wilmink AB. Overview of the epidemiology of colorectal cancer. Dis Colon Rectum. 1997;40(4):483-493. doi:10.1007/BF02258397

10. Ward E, Jemal A, Cokkinides V, et al. Cancer disparities by race/ ethnicity and socioeconomic status. CA Cancer J Clin. 2004;54 (2):78-93. doi:10.3322/canjclin.54.2.78

11. Bach PB, Schrag D, Brawley OW, Galaznik A, Yakren S, Begg CB. Survival of blacks and whites after a cancer diagnosis. JAMA. 2002;287(16):2106-2113. doi:10.1001/jama.287.16.2106

12. Torre LA, Siegel RL, Ward EM, Jemal A. Global cancer incidence and mortality rates and trends - an update. Cancer Epidemiol Biomarkers Prev. 2016;25(1):16-27. doi:10.1158/1055-9965.EPI-15-0578

13. World Cancer Research Fund. Food, Nutrition, Physical Activity, and the Prevention of Cancer: A Global Perspective. Vol. 1. Amer Inst for Cancer Research; 2007.

14. Kim S-E, Paik HY, Yoon H, Lee JE, Kim N, Sung M-K. Sex- and gender-specific disparities in colorectal cancer risk. World J Gastroenterol. 2015;21(17):5167-5175. doi:10.3748/wjg.v21.i17.5167

15. Colussi D, Brandi G, Bazzoli F, Ricciardiello L. Molecular pathways involved in colorectal cancer: implications for disease behavior and prevention. Int J Mol Sci. 2013;14(8):16365-16385. doi:10.3390/ ijms140816365

16. Roper J, Hung KE. Molecular mechanisms of colorectal carcinogenesis. In: Haigis K, editor. Molecular Pathogenesis of Colorectal Cancer. Springer. 2013:25-65.

17. Bardi G, Johansson B, Pandis N, et al. Cytogenetic analysis of 52 colorectal carcinomas-non-random aberration pattern and correlation with pathologic parameters. Int J Cancer. 1993;55(3):422-428. doi:10.1002/ijc. 2910550317

18. Bardi G, Sukhikh T, Pandis N, Fenger C, Kronborg O, Heim S. Karyotypic characterization of colorectal adenocarcinomas. Genes Chromosomes Cancer. 1995;12(2):97-109. doi:10.1002/gcc.2870120204

19. Shih IM, Zhou W, Goodman SN, Lengauer C, Kinzler KW, Vogelstein B. Evidence that genetic instability occurs at an early stage of colorectal tumorigenesis. Cancer Res. 2001;61(3):818-822.

20. Sieber OM, Lamlum H, Crabtree MD, et al. Whole-gene APC deletions cause classical familial adenomatous polyposis, but not attenuated polyposis or "multiple" colorectal adenomas. Proc Natl Acad Sci U S A. 2002;99(5):2954-2958. doi:10.1073/pnas.042699199

21. Powell SM, Petersen GM, Krush AJ, et al. Molecular diagnosis of familial adenomatous polyposis. $N$ Engl $J$ Med. 1993;329 (27):1982-1987. doi:10.1056/NEJM199312303292702

22. Sieber OM, Lipton L, Crabtree M, et al. Multiple colorectal adenomas, classic adenomatous polyposis, and germ-line mutations in MYH. $N$ Engl J Med. 2003;348(9):791-799. doi:10.1056/NEJMoa025283

23. Sparks AB, Morin PJ, Vogelstein B, Kinzler KW. Mutational analysis of the APC/beta-catenin/Tcf pathway in colorectal cancer. Cancer Res. 1998;58(6):1130-1134.

24. Imamura Y, Morikawa T, Liao X, et al. Specific mutations in KRAS codons 12 and 13, and patient prognosis in 1075 BRAF wild-type colorectal cancers. Clin Cancer Res. 2012;18(17):4753-4763. doi:10.1158/1078-0432.CCR-11-3210

25. Baba Y, Nosho K, Shima K, et al. Prognostic significance of AMP-activated protein kinase expression and modifying effect of MAPK3/1 in colorectal cancer. $B r \quad J$ Cancer. 2010;103 (7):1025-1033. doi:10.1038/sj.bjc.6605846

26. Bosetti C, Bertuccio P, Malvezzi M, et al. Cancer mortality in Europe, 2005-2009, and an overview of trends since 1980. Ann Oncol. 2013;24(10):2657-2671. doi:10.1093/annonc/mdt301

27. Edwards BK, Ward E, Kohler BA, et al. Annual report to the nation on the status of cancer, 1975-2006, featuring colorectal cancer trends and impact of interventions (risk factors, screening, and treatment) to reduce future rates. Cancer. 2010;116(3):544-573. doi:10.1002/ cncr. 24760 
28. Torre LA, Bray F, Siegel RL, Ferlay J, Lortet-Tieulent J, Jemal A. Global cancer statistics, 2012. CA Cancer J Clin. 2015;65(2):87-108. doi:10.3322/caac. 21262

29. Navarro M, Nicolas A, Ferrandez A, Lanas A. Colorectal cancer population screening programs worldwide in 2016: an update. World J Gastroenterol. 2017;23(20):3632-3642. doi:10.3748/wjg. v23.i20.3632

30. Young JP, Win AK, Rosty C, et al. Rising incidence of early-onset colorectal cancer in Australia over two decades: report and review. J Gastroenterol Hepatol. 2015;30(1):6-13. doi:10.1111/jgh.12792

31. Arnold M, Karim-Kos HE, Coebergh JW, et al. Recent trends in incidence of five common cancers in 26 European countries since 1988: analysis of the European Cancer Observatory. Eur J Cancer. 2015;51(9):1164-1187. doi:10.1016/j.ejca.2013.09.002

32. Chatenoud L, Bertuccio P, Bosetti C, et al. Trends in mortality from major cancers in the Americas: 1980-2010. Ann Oncol. 2014;25 (9):1843-1853. doi:10.1093/annonc/mdu206

33. Zhang J, Dhakal IB, Zhao Z, Li L. Trends in mortality from cancers of the breast, colon, prostate, esophagus, and stomach in East Asia: role of nutrition transition. Eur J Cancer Prev. 2012;21(5):480-489. doi:10.1097/CEJ.0b013e328351c732

34. Katsidzira L, Gangaidzo IT, Makunike-Mutasa R, et al. A case-control study of risk factors for colorectal cancer in an African population. Eur J Cancer Prev. 2019;28(3):145-150. doi:10.1097/ CEJ.0000000000000439

35. Graham A, Adeloye D, Grant L, Theodoratou E, Campbell H. Estimating the incidence of colorectal cancer in Sub-Saharan Africa: a systematic analysis. J Glob Health. 2012;2(2):020404. doi:10.7189/jogh.02.020404

36. Angelo N, Dreyer L. Colorectal carcinoma - a new threat to black patients? A retrospective analysis of colorectal carcinoma received by the Institute for Pathology, University of Pretoria. $S$ Afr Med J. 2001;91(8):689-693.

37. Cronje L, Paterson AC, Becker PJ. Colorectal cancer in South Africa: a heritable cause suspected in many young black patients. S Afr Med J. 2009;99(2):103-106.

38. Bebington B, Singh E, Fabian J, et al. Design and methodology of a study on colorectal cancer in Johannesburg, South Africa. JGH Open. 2018;2(4):139-143. doi:10.1002/jgh3.12061

39. Cassol E, Malfeld S, Mahasha P, et al. Impaired CD4+ T-cell restoration in the small versus large intestine of HIV-1-positive South Africans receiving combination antiretroviral therapy. $J$ Infect Dis. 2013;208(7):1113-1122. doi:10.1093/infdis/jit249

40. Katalambula LK, Ntwenya JE, Ngoma T, et al. Pattern and distribution of colorectal cancer in Tanzania: a retrospective chart audit at two national hospitals. J Cancer Epidemiol. 2016;2016:3769829. doi:10.1155/2016/3769829

41. Wong MC, Ding H, Wang J, Chan PS, Huang J. Prevalence and risk factors of colorectal cancer in Asia. Intest Res. 2019;17(3):317-329. doi:10.5217/ir.2019.00021

42. Noronha J, deSouza A, Patil P, et al. Management of colon cancer at a tertiary referral center in India - patterns of presentation, treatment, and survival outcomes. Indian J Cancer. 2019;56(4):297-301. doi:10.4103/ijc.IJC 37918

43. Franklyn J, Mittal R, Sebastian T, Perakath B. Demographics and outcomes of surgically treated right sided colon cancer in India: a 9-year single institution experience. Trop Gastroenterol. 2016;37 (1):46-52. doi:10.7869/tg.319

44. Fengju S, Guanglin W, Kexin C. Incidence of colon cancer in Tianjin, China, 1981-2000. Asia Pac J Public Health. 2005;17(1):22-25. doi:10.1177/101053950501700106

45. Wang YG, Chen KX, Wu GL, Song FJ. An analysis: colon cancer mortality in Tianjin, China, from 1981 to 2000. World J Gastroenterol. 2005;11(6):895-898. doi:10.3748/wjg.v11.i6.895
46. Rosenblatt KA, Gao DL, Ray RM, Nelson ZC, Thomas DB. Contraceptive methods and induced abortions and their association with the risk of colon cancer in Shanghai, China. Eur J Cancer. 2004;40(4):590-593. doi:10.1016/j.ejca.2003.09.037

47. Wang X, Lei T, Ma X. [Colon cancer risk factors in Jiashan county, Zhejiang province, the highest incidence area in China]. Zhonghua Zhong Liu Za Zhi. 2001;23(6):480-482. [in Chinese.].

48. Bovell LC, Shanmugam C, Putcha BD, et al. The prognostic value of microRNAs varies with patient race/ethnicity and stage of colorectal cancer. Clin Cancer Res. 2013;19(14):3955-3965. doi:10.1158/10780432.CCR-12-3302

49. Johnson IT, Lund EK. Review article: nutrition, obesity and colorectal cancer. Aliment Pharmacol Ther. 2007;26(2):161-181. doi:10.1111/j.1365-2036.2007.03371.x

50. Willett WC. Diet and cancer: an evolving picture. JAMA. 2005;293 (2):233-234. doi:10.1001/jama.293.2.233

51. Larsson SC, Wolk A. Meat consumption and risk of colorectal cancer: a meta-analysis of prospective studies. Int $J$ Cancer. 2006;119(11):2657-2664. doi:10.1002/ijc.22170

52. Santarelli RL, Pierre F, Corpet DE. Processed meat and colorectal cancer: a review of epidemiologic and experimental evidence. Nutr Cancer. 2008;60(2):131-144. doi:10.1080/01635580701684872

53. Kabat GC, Miller AB, Jain M, Rohan TE. A cohort study of dietary iron and heme iron intake and risk of colorectal cancer in women. $\mathrm{Br}$ $J$ Cancer. 2007;97(1):118-122. doi:10.1038/sj.bjc.6603837

54. de Jong AE, Morreau H, Nagengast FM, et al. Prevalence of adenomas among young individuals at average risk for colorectal cancer. Am J Gastroenterol. 2005;100(1):139-143. doi:10.1111/j.15720241.2005.41000.x

55. Lee KJ, Inoue M, Otani T, Iwasaki M, Sasazuki S, Tsugane S. Physical activity and risk of colorectal cancer in Japanese men and women: the Japan Public Health Center-based prospective study. Cancer Causes Control. 2007;18(2):199-209. doi:10.1007/s10552006-0098-3

56. Bazensky I, Shoobridge-Moran C, Yoder LH. Colorectal cancer: an overview of the epidemiology, risk factors, symptoms, and screening guidelines. Medsurg Nurs. 2007;16(1):46-51; quiz 52.

57. Gallagher EJ, LeRoith D. Obesity and diabetes: the increased risk of cancer and cancer-related mortality. Physiol Rev. 2015;95 (3):727-748. doi:10.1152/physrev.00030.2014

58. Moschos SJ, Mantzoros CS. The role of the IGF system in cancer: from basic to clinical studies and clinical applications. Oncology. 2002;63(4):317-332. doi:10.1159/000066230

59. Avgerinos KI, Spyrou N, Mantzoros CS, Dalamaga M. Obesity and cancer risk: emerging biological mechanisms and perspectives. Metabolism. 2019;92:121-135. doi:10.1016/j.metabol.2018.11.001

60. Meyerhardt JA, Sato K, Niedzwiecki D, et al. Dietary glycemic load and cancer recurrence and survival in patients with stage III colon cancer: findings from CALGB 89803. J Natl Cancer Inst. 2012;104 (22):1702-1711. doi:10.1093/jnci/djs399

61. Zisman AL, Nickolov A, Brand RE, Gorchow A, Roy HK. Associations between the age at diagnosis and location of colorectal cancer and the use of alcohol and tobacco: implications for screening. Arch Intern Med. 2006;166(6):629-634. doi:10.1001/ archinte.166.6.629

62. National Institutes of Health. What You Need to Know About Cancer of the Colon and Rectum. Bethesda, MD, U.S: Department of Health and Human Services \& National Institutes of Health; 2006.

63. Botteri E, Iodice S, Bagnardi V, Raimondi S, Lowenfels AB, Maisonneuve P. Smoking and colorectal cancer: a meta-analysis. JAMA. 2008;300(23):2765-2778. doi:10.1001/jama.2008.839

64. Botteri E, Iodice S, Raimondi S, Maisonneuve P, Lowenfels AB. Cigarette smoking and adenomatous polyps: a meta-analysis. Gastroenterology. 2008;134(2):388-395. doi:10.1053/j. gastro.2007.11.007 
65. Tsong WH, Koh WP, Yuan JM, Wang R, Sun CL, Yu MC. Cigarettes and alcohol in relation to colorectal cancer: the Singapore Chinese Health Study. Br J Cancer. 2007;96(5):821-827. doi:10.1038/sj. bjc. 6603623

66. Poschl G, Seitz HK. Alcohol and cancer. Alcohol Alcohol. 2004;39 (3):155-165. doi:10.1093/alcalc/agh057

67. Haggar FA, Boushey RP. Colorectal cancer epidemiology: incidence, mortality, survival, and risk factors. Clin Colon Rectal Surg. 2009;22 (4):191-197. doi:10.1055/s-0029-1242458

68. Ferrari P, Jenab M, Norat T, et al. Lifetime and baseline alcohol intake and risk of colon and rectal cancers in the European prospective investigation into cancer and nutrition (EPIC). Int $J$ Cancer. 2007;121(9):2065-2072. doi:10.1002/ijc.22966

69. Winawer SJ. The multidisciplinary management of gastrointestinal cancer. Colorectal cancer screening. Best Pract Res Clin Gastroenterol. 2007;21(6):1031-1048. doi:10.1016/j. bpg.2007.09.004

70. Nishihara R, Wu K, Lochhead P, et al. Long-term colorectal-cancer incidence and mortality after lower endoscopy. $N$ Engl $J$ Med. 2013;369(12):1095-1105. doi:10.1056/NEJMoa1301969

71. Kronborg O, Fenger C, Olsen J, Jorgensen OD, Sondergaard O. Randomised study of screening for colorectal cancer with faecal-occult-blood test. Lancet. 1996;348(9040):1467-1471. doi:10.1016/S0140-6736(96)03430-7

72. Allison JE, Lawson M. Screening tests for colorectal cancer: a menu of options remains relevant. Curr Oncol Rep. 2006;8(6):492-498. doi:10.1007/s11912-006-0079-4

73. Center MM, Jemal A, Smith RA, Ward E. Worldwide variations in colorectal cancer. CA Cancer J Clin. 2009;59(6):366-378. doi:10.3322/caac. 20038

74. Lambert R, Sauvaget C, Sankaranarayanan R. Mass screening for colorectal cancer is not justified in most developing countries. Int J Cancer. 2009;125(2):253-256. doi:10.1002/ijc.24371

75. Khuhaprema T, Sangrajrang S, Lalitwongsa S, et al. Organised colorectal cancer screening in Lampang Province, Thailand: preliminary results from a pilot implementation programme. BMJ Open. 2014;4 (1):e003671. doi:10.1136/bmjopen-2013-003671

76. Lopez-Kostner F, Kronber U, Zarate AJ, et al. [A screening program for colorectal cancer in Chilean subjects aged fifty years or more]. Rev Med Chil. 2012;140(3):281-286. doi:10.4067/S003498872012000300001. [in Spanish.].

77. Laiyemo AO, Brawley O, Irabor D, Boutall A, Ramesar RS, Madiba TE. Toward colorectal cancer control in Africa. Int J Cancer. 2016;138(4):1033-1034. doi:10.1002/ijc.29843

78. Chan AT, Ogino S, Giovannucci EL, Fuchs CS. Inflammatory markers are associated with risk of colorectal cancer and chemopreventive response to anti-inflammatory drugs. Gastroenterology. 2011;140 (3):799-808, quiz e711. doi:10.1053/j.gastro.2010.11.041

79. Knupfer H, Preiss R. Serum interleukin-6 levels in colorectal cancer patients - a summary of published results. Int $J$ Colorectal Dis. 2010;25(2):135-140. doi:10.1007/s00384-009-0818-8

80. Song M, Wu K, Ogino S, Fuchs CS, Giovannucci EL, Chan AT. A prospective study of plasma inflammatory markers and risk of colorectal cancer in men. Br J Cancer. 2013;108(9):1891-1898. doi:10.1038/bjc.2013.172

81. Belluco C, Nitti D, Frantz M, et al. Interleukin-6 blood level is associated with circulating carcinoembryonic antigen and prognosis in patients with colorectal cancer. Ann Surg Oncol. 2000;7 (2):133-138. doi:10.1007/s10434-000-0133-7
82. Gunter MJ, Stolzenberg-Solomon R, Cross AJ, et al. A prospective study of serum C-reactive protein and colorectal cancer risk in men. Cancer Res. 2006;66(4):2483-2487. doi:10.1158/0008-5472.CAN05-3631

83. Ogino S, Nosho K, Irahara N, et al. A cohort study of cyclin D1 expression and prognosis in 602 colon cancer cases. Clin Cancer Res. 2009;15(13):4431-4438. doi:10.1158/1078-0432.CCR-08-3330

84. Ogino S, Nosho K, Kirkner GJ, et al. CpG island methylator phenotype, microsatellite instability, BRAF mutation and clinical outcome in colon cancer. Gut. 2009;58(1):90-96. doi:10.1136/ gut.2008.155473

85. Lanza G, Matteuzzi M, Gafa R, et al. Chromosome 18q allelic loss and prognosis in stage II and III colon cancer. Int J Cancer. 1998;79 (4):390-395. doi:10.1002/(SICI)1097-0215(19980821)79:4<390:: AID-IJC14>3.0.CO;2-9

86. Shima K, Morikawa T, Yamauchi M, et al. TGFBR2 and BAX mononucleotide tract mutations, microsatellite instability, and prognosis in 1072 colorectal cancers. PLoS One. 2011;6(9):e25062. doi:10.1371/journal.pone.0025062

87. Chan AT, Baba Y, Shima K, et al. Cathepsin B expression and survival in colon cancer: implications for molecular detection of neoplasia. Cancer Epidemiol Biomarkers Prev. 2010;19 (11):2777-2785. doi:10.1158/1055-9965.EPI-10-0529

88. Baba Y, Huttenhower C, Nosho K, et al. Epigenomic diversity of colorectal cancer indicated by LINE-1 methylation in a database of 869 tumors. Mol Cancer. 2010;9:125. doi:10.1186/1476-4598-9-125

89. Ogino S, Kirkner GJ, Nosho K, et al. Cyclooxygenase-2 expression is an independent predictor of poor prognosis in colon cancer. Clin Cancer Res. 2008;14(24):8221-8227. doi:10.1158/1078-0432.CCR08-1841

90. Liao X, Lochhead P, Nishihara R, et al. Aspirin use, tumor PIK3CA mutation, and colorectal-cancer survival. N Engl J Med. 2012;367 (17):1596-1606. doi:10.1056/NEJMoa1207756

91. Ogino S, Nosho K, Irahara N, et al. Prognostic significance and molecular associations of $18 \mathrm{q}$ loss of heterozygosity: a cohort study of microsatellite stable colorectal cancers. J Clin Oncol. 2009;27 (27):4591-4598. doi:10.1200/JCO.2009.22.8858

92. Morikawa T, Kuchiba A, Liao X, et al. Tumor TP53 expression status, body mass index and prognosis in colorectal cancer. Int $J$ Cancer. 2012;131(5):1169-1178. doi:10.1002/ijc.26495

93. Guerrero S, Casanova I, Farre L, Mazo A, Capella G, Mangues R. $\mathrm{K}$-ras codon 12 mutation induces higher level of resistance to apoptosis and predisposition to anchorage-independent growth than codon 13 mutation or proto-oncogene overexpression. Cancer Res. 2000;60 (23):6750-6756

94. Firestein R, Shima K, Nosho K, et al. CDK8 expression in 470 colorectal cancers in relation to beta-catenin activation, other molecular alterations and patient survival. Int $J$ Cancer. 2010;126 (12):2863-2873. doi:10.1002/ijc. 24908

95. ProCon.org. -O-. US and global obesity levels: the fat chart; 2013. http://obesity.procon.org/view.resource.php?resourceID=004371\#III. Accessed 15 July, 2020.

96. Organization WH. WHO global report on trends in prevalence of tobacco smoking 2015. World Health Organization. 2015.

97. World Health Organization \% J Geneva S. Global status report on alcohol and health-2014. World Health Organization. 2014. 


\section{Publish your work in this journal}

Cancer Management and Research is an international, peer-reviewed open access journal focusing on cancer research and the optimal use of preventative and integrated treatment interventions to achieve improved outcomes, enhanced survival and quality of life for the cancer patient.
The manuscript management system is completely online and includes a very quick and fair peer-review system, which is all easy to use. Visit http://www.dovepress.com/testimonials.php to read real quotes from published authors.

Submit your manuscript here: https://www.dovepress.com/cancer-management-and-research-journa 